\title{
Cultural Cooperation as an Important Area of Strategic Partnership Between China and Russia
}

\author{
Yuyao $\mathrm{Wu}^{1, *}$ \\ ${ }^{1}$ Department of theory and history of international relations, People's Friendship University of Russia, Moscow, \\ Russia \\ *Corresponding author.Email: wu.yuyao@mail.ru
}

\begin{abstract}
The article is devoted to the cultural cooperation between China and Russia at the beginning of the XXI century. In the modern stage China and Russia build bilateral relations with "strategic partnership" character. The aim of the study is to identify the role of cultural cooperation for the Chinese-Russian strategic partnership. To achieve this goal, the following tasks were identified: to analyze the common features of Chinese and Russian cultures, as well as to study the political and conceptual level of development of the cultural component in the national discourses of China and Russia. The using of civilizational and systemic approaches allowed the author to draw conclusion about the cultural aspect plays an important role because it is an integral part of bilateral relations and a promising component of the implementation of national interests.
\end{abstract}

Keywords: China, Russia, Cultural cooperation, Bilateral relation, Strategic partnership, Civilization.

\section{INTRODUCTION}

In the modern realities of the changing international architectonics under the influence of globalization processes bilateral cooperation between states in the cultural aspect is becoming particular importance. Aimed at implementing the foreign policy strategy and achieving national interests by maintaining strong ties between the two peoples and accumulating civilizational imperatives, this aspect is characterized by a comprehensive content and includes interstate cooperation on cultural issues. The outlined potential of this tool of the Sino-Russian strategic partnership, aggravated by its active use in foreign policy, actualizes the study of its application in the bilateral relations of the two states.

Russia and China have stable socio-cultural systems that have preserved their identity and integrity for a significant historical time, despite internal transformation and threats from an external, often aggressive, environment. They are characterized by certain cultural and historical types that can integrate a significant number of local cultures and ethnic communities on the basis of a single worldview and social model.
The aim of this article is to identify cultural cooperation for the Chinese-Russian strategic partnership. To achieve this goal, the following tasks were identified: to analyze the common features of Chinese and Russian cultures, as well as to study the political and conceptual level of development of the cultural component in the national discourses of China and Russia.

The research methodology is based on the civilizational and systemic approaches. The civilizational approach used to analyze their interaction allows us to present all the main systemforming components of society through culture, which is placed at the center of the problems of studying the historical process. Therefore, this approach has not only a great potential for theoretical synthesis, but also a special historiosophical significance. Within the framework of a systematic approach, cultural cooperation between China and Russia is considered as a system of interrelated areas that determine the degree of realization of mutual interests. This study uses a comparative analysis method to identify common features in the culture of China and Russia, as well as to correlate the level of conceptual security of bilateral relations. 


\section{INTERACTION OF CULTURES OF CHINA AND RUSSIA: THE PROBLEM OF COMPATIBILITY}

Since the initial period of establishing bilateral ties in the XVII century, a significant cultural distance between Russia and China has been revealed. One of the most authoritative experts in the field of bilateral relations in the Far Eastern region, V. L. Larin, writes: "The two civilizations, the Slavic and the Chinese, do not give in to mutual assimilation, do not mix, which gave rise to many problems of an ethno-cultural nature in the process of their interaction." However, there is an opposite point of view [1]. Therefore, experts G. Krieger and Zheng Jia note the spiritual closeness of our cultures [2].

Without detracting from the theoretical significance of this discussion, we should focus on the general features that positively affect the dialogue between the two cultures. The first similarity is their high-contextuality, according to the typology of E. Hall [3]. This wealth, inherited by the culture, testifies to the preservation of the deep historical tradition of the two civilizations. At the same time, it is necessary to take into account the existing differences in the contexts themselves. In addition to the dividing effect, they stimulate mutual interest, and the considerable distance between cultural systems determines the high creative potential of the cultural dialogue between China and Russia. Highly contextual cultures are characterized by the following features that determine the behavior patterns of their carriers: an unspoken, hidden manner of speech; a large semantic content of the unspoken; an important role of nonverbal communication [4]. The commonality in the behavior of the participants in the dialogue creates a trusting atmosphere that promotes their mutual understanding and better adaptation in a foreign cultural environment.

Another significant quality of the cultures of China and Russia is a significant assimilation experience. Over their centuries-old history, both nations have integrated the cultures of numerous peoples who have interacted with them. The assimilation potential has formed a serious communicative resource of the Chinese and Russian cultures, which can be realized in their further interaction [5].
An important component of the picture of the world, which sets the sequence of events and the rhythm of life in any society, is the concept of time. From this point of view, it is necessary to consider the stability of the calendar traditions of Russia and China. Chinese and Russian cultures are based on the idea of a cyclical flow of time, a straight line of progress is alien to them. This forms a commonality in the perception of time, in which much happens simultaneously and is understood not as a straight path, but as a kind of knot of intertwining many problems [6]. A common feature of cultures, which has a significant potential for dialogue, is the large role of interpersonal informal relationships. This is evidenced by the rich experience of communication between the population of the Russian Far East and China during the study period. Personal agreements, the communication itself, are considered more important than the adopted action plan, and often even-the benefit. Representatives of polychronous cultures are more dynamic in dealing with time, while punctuality and daily routine are not given much importance.

A significant communicative aspect is that China and Russia belong to societies with a high distance in the relations of the people and the authorities, with developed traditions of collectivism in accordance with the theory of cultural dimensions by G. Hofstede. The cultures of both countries are characterized by paternalism. In the ideal model, the State's policy towards its citizens is aimed at comprehensively guiding the development and well-being of all citizens. The actions of the authorities that contradict these stable ideas cause a crisis of legitimacy.

\section{CONCEPTUALIZATION OF CULTURAL COOPERATION BETWEEN CHINA AND RUSSIA}

In parallel with the growth of China's economy and military capabilities in the 21 st century, China's domestic political discourse has shifted from socialist values to traditional Chinese culture and history. Throughout the 2000s, the PRC's diplomacy mainly operated with ideas that emphasized the traditionally peaceful nature of Chinese culture. In addition, China is striving to promote its national culture, especially in the partner countries, which was facilitated by the organizational base and financial capabilities. 
As the country's foreign policy activity intensified, the political leadership developed a value base to support its policy. Proclaimed in 2005, Chinese President Hu Jintao's idea of a "harmonious" world (和谐世界 - hexie shijie) was intended to increase social responsibility and interconnectedness. At the 18th CCP Congress (2012), Hu Jintao named uniqueness (独特性 dutexing) and tolerance (包容性 - baorongxing) as the "core values" of Chinese culture in the 21st century. The Chinese "view of values" was clearly outlined, which implies twelve components: at the state level - wealth and power, democracy, civilization, harmony; at the society level freedom, equality, justice and the rule of law; at the human level - patriotism, dedication, honesty, friendship and kindness [7]. Therefore, the Chinese leadership has laid a value foundation for improving the image component of its global strategy of "going abroad" and related concrete steps on the world stage.

The cultural agenda in the foreign policy of the People's Republic of China has gained a special impetus since the proclamation by the President of the People's Republic of China Xi Jinping of the concept of building a "community of the common destiny of mankind" ( 人类命运共同体 - renlei mingyun gongtongti) in 2012. This concept reflects the view of the Chinese leadership on the reform of the modern world political structure and the establishment of China's role as one of the main architects of the world order for the foreseeable future. Focusing on diplomacy, the economy, security and the environment, Xi Jinping's construct also touches on the cultural sphere. In this direction, the Chinese side proposed to promote exchanges between civilizations "on the condition of mutual respect, borrowing positive aspects, harmonious coexistence" and recognize the ideas of the superiority of one civilization over another as untenable and destructive [8].

In Xi Jinping's report to the 19th National Congress of the CPC, the task of promoting cultural cooperation to build a community of common destiny remained the same. The Chinese leader again stress, that China should "promote intercivilizational exchanges involving harmonious coexistence while preserving identity, mutual perception and complementarity". However, the role of Chinese culture itself in this inter- civilizational exchange was stipulated. The necessity of introducting the best achievements of advanced socialist culture with Chinese characteristics was emphasized, and the source of this is "the outstanding traditional culture of China, formed during more than five thousand years of the history of Chinese civilization" [9]. Thus, Xi Jinping has built a clear logic for dialogue with the international community, where the cultural aspect plays a significant role.

The foreign policy concept has a material embodiment associated with the implementation of the infrastructure initiative "the Belt and Road Initiative", which also contains a "cultural" subtext. At the Silk Road 2017 forum, the Chairman noted that the initiative is aimed at building a "path of joint civilizational development" and stressed the need to promote the dialogue of civilizations and attach great importance to cultural cooperation [10]. Therefore, "the Belt and Road Initiative" initiative appears as an implementation of the traditional Chinese approach to foreign policy. As the basic principles of "the Belt and Road Initiative" (as well as the "community of a single destiny of humanity") traditional Chinese values such as friendship, sincerity, kindness, and inclusiveness stand out [11].

Such attention to the normative elaboration of the concept of the "Community of One Destiny" and the economic initiatives that fill it with content, allows us to talk about China's elevation of the humanistic concept to the rank of state policy. This corresponds to the theory of the authoritative scholar from Tsinghua University, Yang Xuetong, about "moral leadership" (王权 - wanquan). He argues that the most powerful state in the international system should develop relations with other countries on the basis of mutual respect. All benevolent actions of the leader should be guided by morality, not by force [12]. The creation of a "system of true values" with an emphasis on such qualities as justice (公正 - gongzheng) and rationality (合理 - heli) provides an alternative in the conditions of the dominance of "universal values in the Western sense" [13]. Should be assumed that the new foreign policy concept will only strengthen the formatting of the image component of the benevolent and moral subject in China's rhetoric, which stimulates the cultural component in relations with Russia. 
The main directions of the Russian Federation's policy in the field of cultural cooperation are reflected in the document of the same name, developed by the Russian Foreign Ministry in December 2010 [14]. The importance of this direction was explained by the need to create a favorable image of the country abroad and meet the interests of increasing the number of friends of Russia, countering the drawing of new dividing lines, neutralizing anti-Russian sentiments of political and ideological origin. In addition, this document contains a view on cultural cooperation as a means of overcoming the negative consequences of globalization, as well as maintaining stable and long-term ties between States, public organizations and people.

The support of international cultural contacts is currently designated as one of the priority areas of state policy [15]. The "Concept of Foreign Policy of the Russian Federation" of 2016 identifies strengthening the position of the Russian language in the world, popularizing the achievements of national culture, national historical heritage and cultural identity of the peoples of Russia, Russian education and science, and consolidating the Russian Diaspora as the main tasks of implementing the strategic national priorities of the Russian Federation [16]. Among the mechanisms for achieving such important tasks for Russian foreign policy, the Russian leadership considers both interstate interaction and cooperation with international non-governmental organizations, and calls the resource of public diplomacy a means of inter-civilizational dialogue.

Based on the content of the fundamental legal documents, it can be stated that in Russia the concept of "cultural and humanitarian relations" includes the importance of establishing and maintaining international contacts in the field of education, culture, science, mass communications, etc.

These maxims predictably caused a discussion in the Russian scientific community. Experts conclude that for the effective implementation of national goals through the humanitarian aspect of the Russian Federation, it is necessary to create its own logical link that would meet the image and mission of Russia in a complex multipolar world and see great potential in using the values of peaceful coexistence of peoples, as well as focusing on multinational, federal and unity with compatriots abroad [17]. Specialist in the field of applied analysis of international relations A. V. Biryukov notes that Russia needs to be reminded of the spiritual sphere of its development with the help of tools of conscious influence, namely, the richest culture, religion, traditionally strong family and kinship ties, powerful science, etc. [18]. When searching for a foundation for improving the effectiveness of humanitarian relations, discussions are also held about the material potential of their implementation.

The economic factor plays an important role in the development of cooperation in the humanitarian sphere. Despite the fact that the potential of humanitarian cooperation is quite large, the problem is the timely material and financial support for the implementation of this potential. To make the creation of common educational, informationized, scientific and cultural space in demand will largely allow the active development of economic integration [19]. Thus, the process of intensifying humanitarian relations is directly dependent on the development of bilateral economic initiatives.

\section{CONCLUSION}

We should notice that for both China and Russia, the cultural aspect is an integral part of bilateral relations and is considered as a promising component of the implementation of national interests. However, given the level of conceptualization and ideological content of this aspect in the foreign policy of the two states, Russia is in a somewhat reactive role against the background of its partner, which, implementing major political and economic initiatives and giving them both rational and value characteristics, is interested in establishing an intercultural dialogue to form an image that meets the image policy of the country.

Summing up, it is worth noting once again the importance of cultural cooperation in the modern Sino-Russian relations of strategic partnership. In cultural cooperation, culture is used as an object and means of achieving the fundamental goals of the state's foreign policy, creating a favorable image of the country, and popularizing the culture and languages of its peoples. The high degree of similarity of the fundamental phenomena of 
Chinese and Russian cultures increases the potential of bilateral cooperation in unstable geopolitical conditions.

\section{AUTHOR'S CONTRIBUTIONS}

This paper is independently completed by Yuyao $\mathrm{Wu}$.

\section{REFERENCES}

[1] Larin, V. L. China and the Russian Far East in the first half of the 90s: problems of regional cooperation. Vladivostok: Dalnauka, 1998. p. 153-154. (in Russian)

[2] Krieger, G. N., Jia Zheng. Specificity of psychological adaptation in the conditions of modern cultural space on the example of Russian and Chinese cultures / / Actual problems of ethnopsychology in the context of cultural and economic cooperation with the countries of the Asia-Pacific region. 2008. Vol. 1. p. 221-236. (in Russian)

[3] Hall E.T. Beyond Culture. N.Y.: Anchor Books, 1989. p. 128.

[4] Appadurai A. Disjuncture and Difference in the Global Cultural Economy // Global Culture (ed. by M. Featherstone). London. 1990. p. 296

[5] Melikhov G. V. Manchuria far and near. Moscow: Nauka. 1991. p. 3-5. (in Russian)

[6] Ter-Minasova S.G. In Search of National Character // The XXVI Annual International Academic Conference, Language and Culture. 27-30 October, 2015. p. 20-25.

[7] 18th National Congress of the Communist Party of China. Key Quotes from Hu Jintao's Report to the 18th CPC National Congress // Beijing Leisure, November 15, 2012. No 42. p. 12.

[8] Xi Jinping Attends General Debate of 70th Session of the UN General Assembly and Delivers Important Speech, Underlying to Inherit and Advocate Purposes and Principles of the UN Charter, Establish New Type of International Relations with Win-Win Cooperation as Core and Build Community of
Shared Mankind Destiny. 29.09.2015. URL: https://www.fmprc.gov.cn/mfa_eng/zxxx_662 805/t1817766.shtml (accessed: 07.04.2021).

[9] Xi Jinping. Zai zhongguo gongchandang di shijiu ci quanguo daibiao dahui shang de baogao [Xi Jinping. Report at the 19th National Congress of the CPC]. URL: http://cpc.people.com.cn/n1/2017/1028/c6409 4-29613660-15.html (accessed: 07.04.2021).

[10] Han Qingxiang, Chen Yuanzhang. Renlei mingyun gongtongti yu zhonghua xin wenming. [Community of the common destiny of mankind and the new Chinese civilization]. Xuexi shibao [Study Times], 2017. p. 3 (in Chinese).

[11] Gong Ting. "Yidai yilu" changyi de zhongguo chuantong sixiang yaosu chutan. [Study of traditional Chinese thought in the "one belt, one road" initiative]. Dangdai shijie yu shehuizhuyi [Contemporary world and socialism], 2015. p. 12. (in Chinese).

[12] Yan Xuetong. Gongping zhengyi de jiazhiguan yu hezuo gongying de waijiao yuanze [Justice and win-win diplomatic cooperation]. Guoji wenti yanjiu [Research on international issues], 2013 (in Chinese).

[13] Heike H. Shifting Ideologics of Research Funding: The CPC's National Planning Office for Philosophy and Social Sciences // Journal of Current Chinese Affairs, № 2, 2014. P. 1332.

[14] The main directions of the Russian Federation's policy in the field of international cultural and humanitarian cooperation. 18.12.2010. URL: https://www.mid.ru/foreign_policy/official_do cuments/-/asset_publisher/CptICkB6BZ29 /content/id/ 224550 (accessed: 07.04.2021).

[15] Order of the Government of the Russian Federation № 326-p 29.02.2016 "On Approval of the Strategy of the State Cultural Policy for the Period up to 2030" // Collection of Legislation of the Russian Federation. 14.03.2016. № 11. p. 15-19.

[16] The concept of the foreign policy of the Russian Federation. November 30, 2016. 
URL: https://www.garant.ru/ products/ipo/prime/doc/71452062/ (дата обращения: 02.03.2020).

[17] Leonova, O.G. Myagkaya sila: Instrumenty i koeffitsiyenty vliyaniya. ObozrevatelObserver, № 3 (2014): 18-28 (in Russian). Smorodina, Yu.V. "Myagkaya sila" Rossii i puti povysheniya eye effektivnosti. Rossiya i sovremennyy mir, № 3 (2017): 290-292 (in Russian).

[18] Biryukov A.V. Spiritual foundations of the country's development. // Center for SocialConservative Policy. 20.03.2008. URL: cskp.ru/2008/03/20/a-v-biryukov-duhovnyeosnovy-razvitiya-strany/ (accessed: 07.04.2021).

[19] Velikaya A. A. International humanitarian cooperation: political aspects of domestic and Western approaches // Law and administration. XXI century. № 3 (24) 2012, p. 63-72. 